\title{
Evaluation of Mobile Educational Applications as Support in the Teaching-Learning Process of the Module Fundamentals of Mathematics at the National Polytechnic School
}

\author{
Christian Alcócer, MSc ${ }^{1}$, Malena Loza, $\mathrm{MSc}^{1}$, Julio Merizalde, $\operatorname{Ing}^{1}$, Telmo Perugachi, MSc ${ }^{1}$, Iván Sandoval, MSc ${ }^{1}$ \\ ${ }^{1}$ Escuela Politécnica Nacional, Ecuador \\ christian.alcocera@epn.edu.ec, malena.lozal@epn.edu.ec, julio.merizalde@epn.edu.ec, telmo.perugachib@epn.edu.ec, \\ ivan.sandoval@epn.edu.ec
}

\begin{abstract}
Nowadays, the globalized world encourages people to be able to use ICT's in every aspect of their life. Several mobile apps have been created to support the learning process. Particularly, the teaching of Mathematics has benefited from the use of innovative mobile apps. This study evaluates the most common mathematical educational apps through a survey answered by teachers and students from the module of Fundamentals of Mathematics at National Polytechnic School (EPN). The study reveals that WolframAlpha is the most appropriate app to support the learning process. The $81 \%$ of students consider that the use of this app could improve their academic outcomes and the $100 \%$ of teachers agree to include them in the teaching-learning process

Keywords-- Educational apps, teaching-learning process, academic performance, ICT's, highest education
\end{abstract}

\section{INTRODUCTION}

Every day, our society undergoes a constant transformation in which the use of information and communication technologies (ICT's) has become essential in our lifestyle. Nowadays, it is hard to think of individuals who do not possess an element of those that belong to the ICT's, for instance, a desktop computer, a smartphone, or even internet access. The use of the ICT's contribute to a globalization process in all aspects of society including innovation, entertainment, trading and education.

The use of ICT's as a tool for the educational process is a collaborative task between teachers, students and technology providers. As an educational resource, the ICT's focus on the transfer of knowledge through technological means. The development of teaching and learning methodologies should be supported by the ICT's. In other words, technological tools should be incorporated into the classroom to improve the learning process and the academic performance of students. Some of those tools are digital books, educative videos, educative apps, tutorials and virtual classrooms. All these resources should be used in conjunction with teachers and students as a way for strengthening the learning process inside and outside the classroom [1].

Mobile devices inside the classroom are not anymore a paradigm for teachers and students around the world. For this reason, several software developers have implemented various

Digital Object Identifier (DOI): http://dx.doi.org/10.18687/LACCEI2018.1.1.246 ISBN: 978-0-9993443-1-6

ISSN : $2414-6390$ educational applications. Among those apps, the majority of them are free of charge or can be used from a mobile browser. Consequently, their use will not present any restriction neither for students nor for teachers.

In Ecuador, government agencies responsible for regulating the academic activities of higher education institutions encourage the use of new ICT's. The Higher Education Council (CES) through the Organic Law for Higher Education (LOES) establishes that universities and polytechnic schools must ensure the pedagogical-technical resources that guarantee the learning process for students [2]. These resources include laboratories as well as hardware and software tools with the aim to support academic activities.

Moreover, the Regulation of Academic Regime emitted by the CES suggests the use of the ICT's as an essential method of learning activities. The CES considers that a perfect harmony between educational resources and ICT's represents a relevant tool that enhances the interaction channels between teachers and students; therefore, it contributes in a positive manner to the learning process [3]. Additionally, the CES recognizes that mastering the use of ICT's should be one of the primary fields of professional training in technical education as well as higher education at both third and fourth levels.

Despite the aforementioned regulations, the higher education system in Ecuador has not presented a substantial difference with respect to the use of ICT's due to several factors. One key factor is that the majority of learning processes follow a classic structure. Equally important, the use of technological applications may represent a complex task for some teachers and students. Furthermore, there is a lack of access points and network availability in universities. To put it differently, the Ecuadorian higher education system is in a static process about the use of ICT's. For this reason, it is necessary to develop a process to incorporate technological tools in the teaching process of higher education institutes.

Considering the regulations of the CES, the National Polytechnic School (EPN) through its Information and Processes Management Directorate (DGIP) has developed a plan to integrate ICTs in their teaching, research and administration processes. The Strategic Plan of Information Technologies 2015 - 2020 stimulates two important strategies for the use of ICT's in the teaching process: to strengthen the 
learning environment and to enrich the students experience. To achieve those goals, this Plan proposes the adoption of new technological platforms in all teaching-learning processes [4].

In addition to the current education regulations mentioned, there are low levels of approval among students of the Basic Training Department at EPN, as shown in [5]. For instance, of all students enrolled in the engineering levelling courses for the academic period 2016-A, only a $28 \%$ achieves a passing grade, including those students from both first and second enrollment [5]. Consequently, it is necessary to include in the basic training modules new methodologies that increase the approval levels of the students of the EPN like educational mobile apps.

The use of ICTs as an educational tool at the EPN is proposed as an aid that will be provided to students for their academic reinforcement. At first, this study will be carried out within the Basic Training Department of the EPN, in which the modules of Fundamentals of Mathematics, Physics, Chemistry and Geometry are taught. The impact of the use of educational apps in the module Fundamentals of Mathematics will be analyzed.

Currently, several mobile apps and web pages aid in the solution of various types of mathematical problems. However, in this study, those apps related to pre-calculus topics will be evaluated. The aim of this analysis is to select the ideal educational app which is expected to help students on their academic performance.

The remainder of this paper is organized as follows: Section 2 talks about the methodology, and it refers to the procedures timetable in this research. The third Section is the Result analysis, and it describes the polls tabulation with their evaluation. Finally, in the last section, the conclusions are shown, and all the possible recommendations which are suggested for a further research.

\section{METHODOLOGY}

In order to know the degree of contribution that mobile apps can offer to the teaching-learning process into the module Fundamentals of Mathematics, the most used apps were assessed. The outcome of this evaluation is to know if this kind of educational apps might improve the academic performance of students.

The first step in the process of evaluation was to make a comparative analysis of the most popular and well-known apps in the app store as can be shown in Table 1. To summarize, all of the apps are able to be used in the teaching-learning process. Applied correctly, not as a replacement of the traditional method, they would help to visualize in an interactive way the resolution of several mathematical problems.

TABLE 1 [6]

CoMPARATIVE TABLE OF THE MAIN APPS

\begin{tabular}{|c|c|c|c|c|c|}
\hline $\begin{array}{l}\text { Rarameter } \\
\text { App }\end{array}$ & Engagement & Pedagogy & Support & Pros & Cons \\
\hline Photomath & $\begin{array}{l}\text { Students will be engaged } \\
\text { as they take photos of } \\
\text { equations and see the } \\
\text { solutions appear on the } \\
\text { screen, but the novelty } \\
\text { wears off quickly. }\end{array}$ & $\begin{array}{l}\text { Could be an innovative } \\
\text { way for students to see } \\
\text { steps for solving } \\
\text { equations, however, steps } \\
\text { are not explained, they } \\
\text { are simply listed. }\end{array}$ & $\begin{array}{l}\text { A tutorial will show how } \\
\text { to use the app. Simple, } \\
\text { clean design makes } \\
\text { navigation a snap. } \\
\text { Voiced instructions could } \\
\text { appeal to diverse } \\
\text { learners. }\end{array}$ & $\begin{array}{l}\text { Offers a unique, tech- } \\
\text { savvy approach to } \\
\text { showing solutions to } \\
\text { math equations. }\end{array}$ & $\begin{array}{l}\text { Students could be } \\
\text { tempted to use the app } \\
\text { for quick and easy } \\
\text { answers to problems, } \\
\text { with no opportunity for } \\
\text { in-depth learning. }\end{array}$ \\
\hline $\begin{array}{c}\text { Wolfram } \\
\text { Alpha }\end{array}$ & $\begin{array}{l}\text { Students can freely } \\
\text { explore their choice of } \\
\text { topics. Answers rely on } \\
\text { info housed in Wolfram } \\
\text { Alpha's databases. Not } \\
\text { all factual questions can } \\
\text { be answered, which } \\
\text { could turn people away. }\end{array}$ & $\begin{array}{l}\text { Wolfram Alpha shares } \\
\text { everything it knows } \\
\text { using text, diagrams, and } \\
\text { pictures. Students will } \\
\text { need more support to } \\
\text { apply the data elsewhere. } \\
\text { Answers and reports can } \\
\text { be shared on social } \\
\text { networking sites. }\end{array}$ & $\begin{array}{l}\text { A video tutorial, } \\
\text { community forum, and } \\
\text { blogs are available. } \\
\text { Different presentations of } \\
\text { data may engage kids } \\
\text { who are not strong } \\
\text { readers. }\end{array}$ & $\begin{array}{l}\text { It answers questions } \\
\text { directly rather than } \\
\text { pointing to another } \\
\text { source. }\end{array}$ & $\begin{array}{l}\text { Capabilities depend on } \\
\text { what is in the database; } \\
\text { not all questions can be } \\
\text { answered. }\end{array}$ \\
\hline GeoGebra & $\begin{array}{l}\text { It is interactive and } \\
\text { challenging, but students } \\
\text { might get frustrated and } \\
\text { give up if they do not get } \\
\text { clear directions. Teachers } \\
\text { can create interactive } \\
\text { worksheets to target their } \\
\text { students' specific } \\
\text { interests }\end{array}$ & $\begin{array}{l}\text { Kids create their own } \\
\text { understanding by } \\
\text { building and modifying } \\
\text { mathematic } \\
\text { constructions. } \\
\text { Simulations help students } \\
\text { use math to model real- } \\
\text { world situations. }\end{array}$ & $\begin{array}{l}\text { Available in many } \\
\text { different languages, } \\
\text { including English, } \\
\text { Japanese, Spanish, and } \\
\text { Turkish. Extensive } \\
\text { introductory materials } \\
\text { include video tutorials } \\
\text { and a user forum. }\end{array}$ & $\begin{array}{l}\text { Vast number of flexible } \\
\text { math simulations allow } \\
\text { for creation, } \\
\text { modification, and real- } \\
\text { world learning }\end{array}$ & $\begin{array}{l}\text { It takes time for teachers } \\
\text { and kids to learn how to } \\
\text { use the software, and } \\
\text { user-generated content } \\
\text { varies in quality }\end{array}$ \\
\hline Symbolab & $\begin{array}{l}\text { By offering access to the } \\
\text { camera, students can take } \\
\text { a picture of the problem } \\
\text { to solve. Solutions can be } \\
\text { shared through email, } \\
\text { message, and social } \\
\text { media. }\end{array}$ & $\begin{array}{l}\text { Symbolab Calculator } \\
\text { offers answers to } \\
\text { complex math subjects } \\
\text { that not everyone is able } \\
\text { to solve, quickly and } \\
\text { easily. Visual } \\
\text { representations of graphs } \\
\text { and charts also aid } \\
\text { learning. }\end{array}$ & $\begin{array}{l}\text { Examples in each } \\
\text { category offer templates } \\
\text { that assist with } \\
\text { correctly inputting } \\
\text { numbers into challenging } \\
\text { problems. }\end{array}$ & $\begin{array}{l}\text { Offers quick answers to } \\
\text { complicated math } \\
\text { equations related to } \\
\text { algebra, calculus, } \\
\text { trigonometry, and other } \\
\text { higher-level math } \\
\text { problems. }\end{array}$ & $\begin{array}{l}\text { Steps to solve, which } \\
\text { would offer more } \\
\text { educational value, are } \\
\text { only included in the paid- } \\
\text { for version. }\end{array}$ \\
\hline
\end{tabular}

$1^{\text {th }}$ LACCEI International Multi-Conference for Engineering, Education, and Technology: "Innovation in Education and Inclusion", 19-21 July 2018, Lima, Peru. 
Fig 1 shows a flowchart that describes all the activities performed in this study.

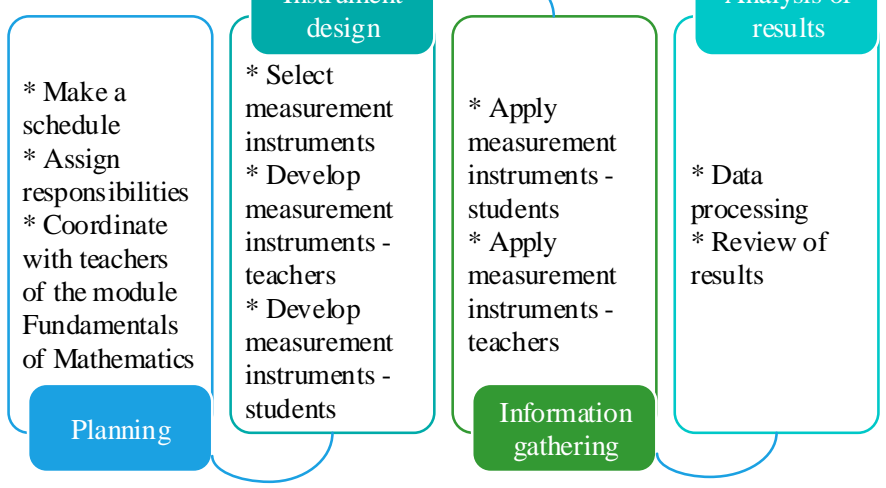

Fig. 1 Process for evaluating the degree of contribution of mobile apps in the teaching-learning process of the module Fundamentals of Mathematics.

\section{A. Planning}

The aim of this subprocess is to set up all the parameters in the research, define a work timetable, deadlines, and the human resource, which will help to gather information.

\section{B. Instruments Design}

The instruments defined for the collection of information were surveys with similar approaches for both teachers and students. In addition, students answered a second final poll that evaluates one specific app.

The students' poll as shown in Fig. 2 has seven questions that explore if students have their own mobile device, if they use them in an academic way, and to know for which subject they use their mobile device as an academic resource.

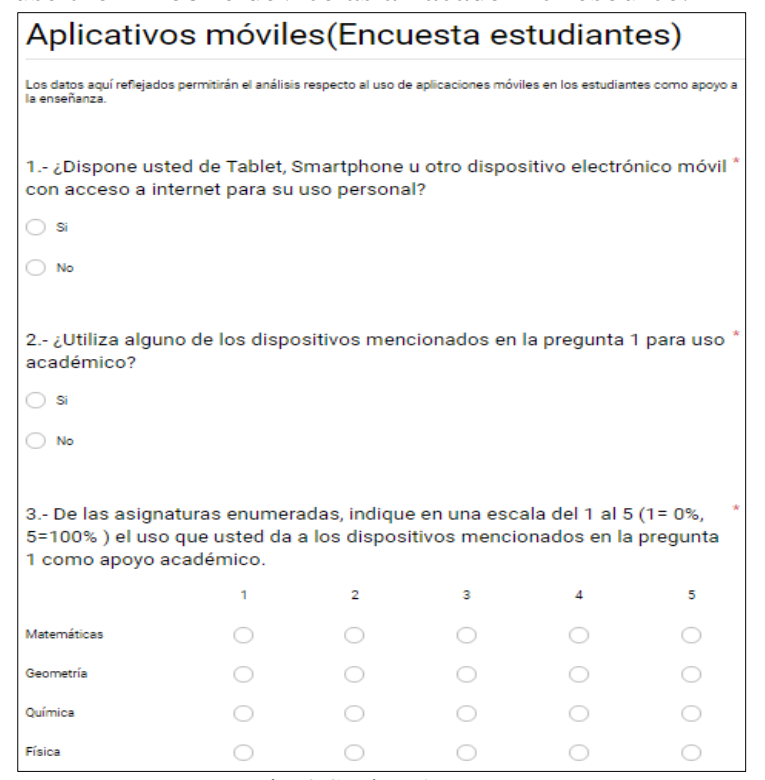

Fig. 2 Students' survey

The four most popular educational apps were selected. The purpose of the survey was to know which of those apps is the most used by the students of the module Fundamentals of Mathematics or if there exists an additional app known among students. Another purpose of the poll was to know the percentage of use of each app, and if the use of those educational apps would have improved the academic performance of students.

The lecturer's poll can be seen in the Fig. 3. This poll has a similar structure to the student's survey. The target of it is to know what is the age range of the lecturers at EPN and if they have an electronic device for personal and academic use. Another goal of the survey is to recognize if lecturers know and use those apps identified by students.

Finally, it is important to identify if lecturers are willing to use this kind of apps in the teaching process and if they believe that these apps could help their students' academic performance.

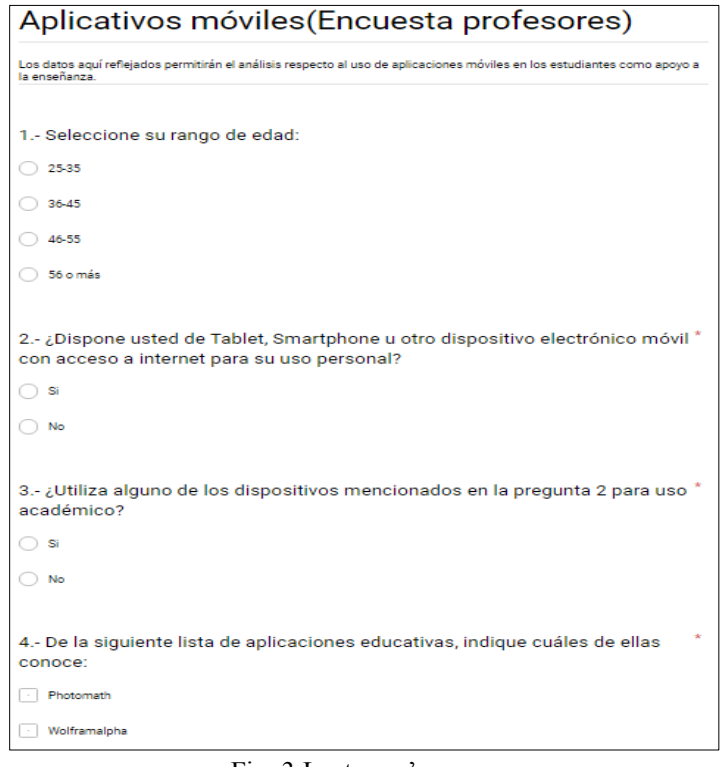

Fig. 3 Lecturers' survey

The last poll, as seen in Fig. 4, was applied to the students after they solved some mathematical problems focused on precalculus. This survey wants to show the utility of one specific app.

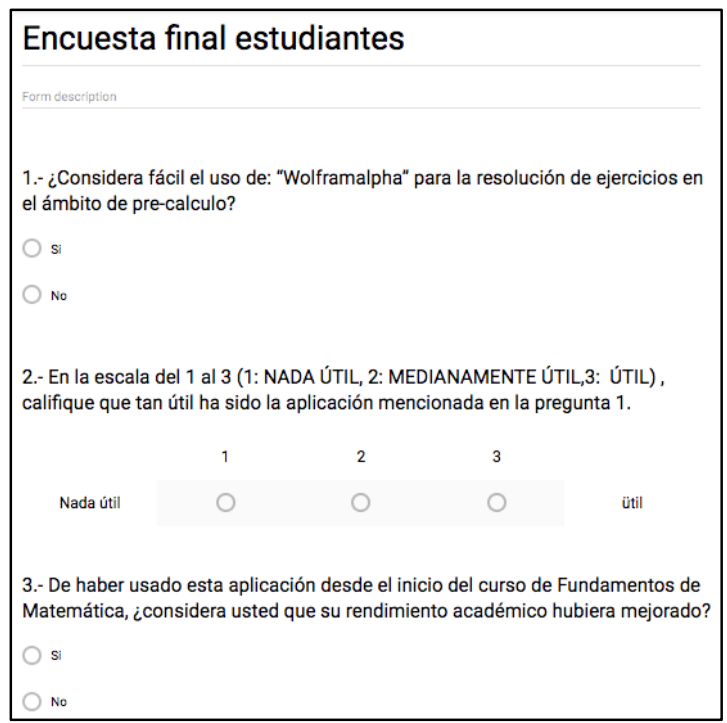

Fig. 4 Students' final survey

$1^{\text {th }}$ LACCEI International Multi-Conference for Engineering, Education, and Technology: "Innovation in Education and Inclusion”, 19-21 July 2018, Lima, Peru. 


\section{Information Gathering}

Online polls were distributed to be filled by both lecturers and students of the module Fundamentals of Mathematics. The study was performed with the participation of 24 lecturers and 164 students.

\section{Tabulation of Polls}

After verifying that the collected information was consistent, all data were processed and analyzed question by question and between questions. After this analysis, it will be observed if both lecturers and students accept mobile educational apps; and if their use would improve the academic performance of students.

\section{RESULTS ANALYSIS}

\section{A. Students' First Survey}

The results of this poll show that the $99 \%$ of students have an electronic device for their personal use. This result indicates that the use of this type of devices is common among students. One relevant finding is that the $98 \%$ of the surveyed students use their electronic devices for academic purposes This datum evidences a more formal use of these tools to support the education process.

Into the module Fundamentals of Mathematics, results show a great use of electronic devices as an academic support in around $76.7 \%$ taking into account ranges between $3(50 \%)$ and $5(100 \%)$. These percentages can be seen in Fig. 5.

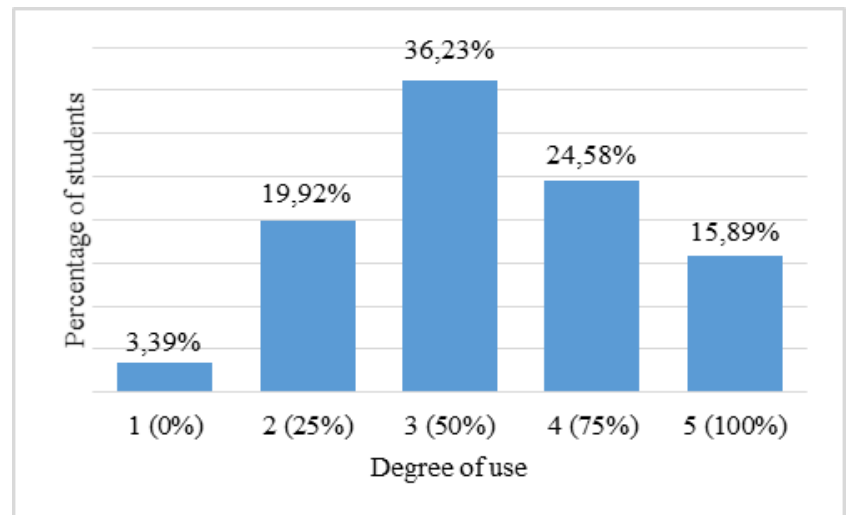

Fig. 5 Using of electronic devices as support in Mathematics

This poll also reveals that the most well-known apps are Geogebra, WolframAlpha, Photomath and Symbolab with $84.8 \%, 66.55 \%, 62.8 \%$ and $36 \%$, respectively.

Fig. 6 and Fig. 7 present percentage of use of Geogebra and WolframAlpha, respectively. Even though these apps are wellknown among students, they have a low percentage of use. Considering occasional, frequent and permanent usage, only a $56.05 \%$ of students use Geogebra and a $43.48 \%$ WolframAlpha. These results might show that many students do not know the real utility of these applications as a support in the learning method.

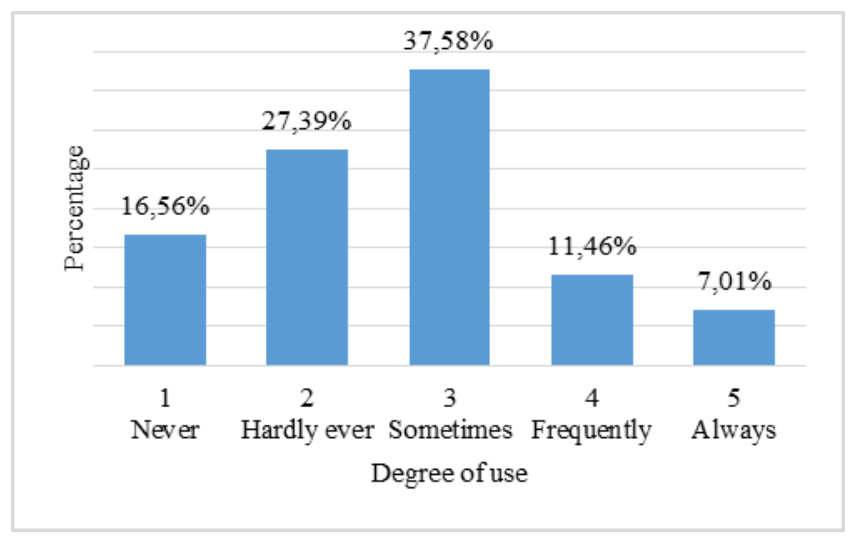

Fig. 6 Use of GeoGebra

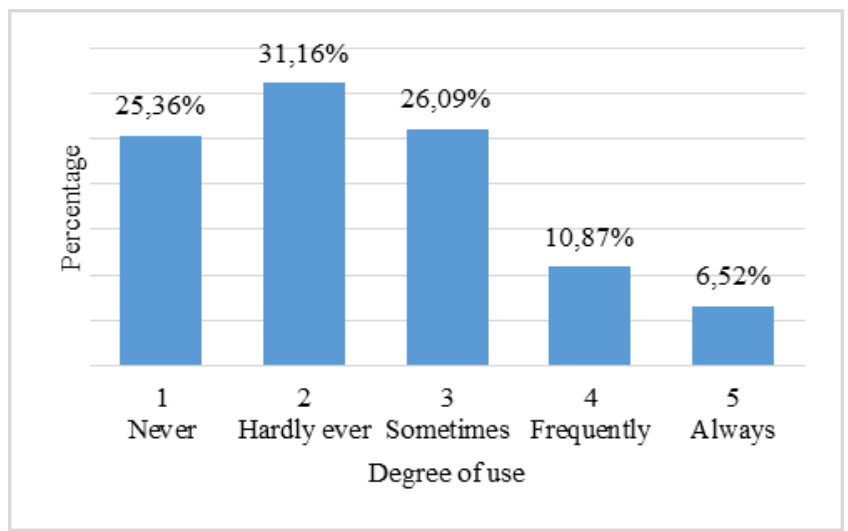

Fig. 7 Use of WolframAlpha

Students believe that these technological tools should be included in the learning process. The survey reflects that the $92.91 \%$ of the students suggest that these mobile apps should be part of the lecturer teaching tools. As can be seen in Fig 8, most of the students (93\%) think that the use of any educational app would definitely help them in order to increase their academic performance.

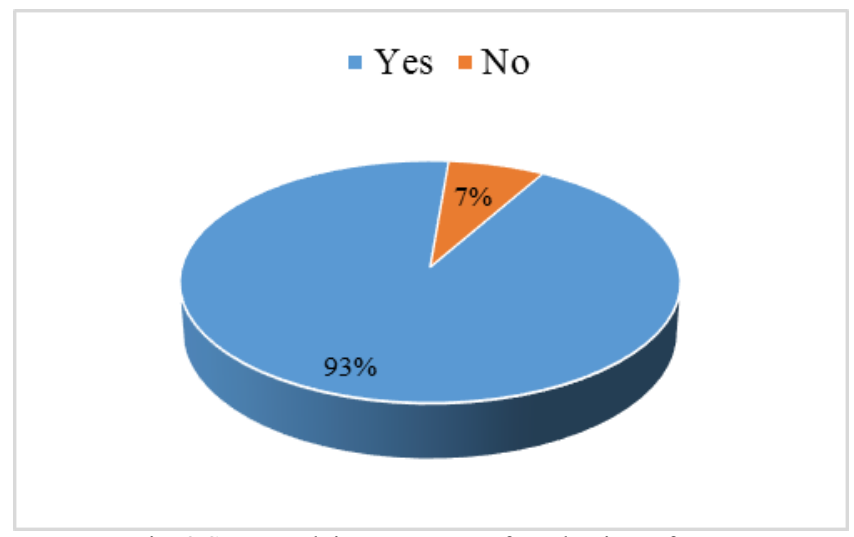

Fig. 8 Suggested improvement of academic performance

\section{B. Lecturers' Survey}

As seen in Fig. 9, the most popular apps are WolframAlpha and Geogebra both with a $91.3 \%$ of lecturers that know them, followed by Symbolab with a 52.2\% and Photomath with a

$1^{\text {th }}$ LACCEI International Multi-Conference for Engineering, Education, and Technology: "Innovation in Education and Inclusion”, 19-21 July 2018, Lima, Peru. 
$39.1 \%$. These results show that the teaching process develops in a globalized environment that tends to the use of technological tools to support the lecturer.

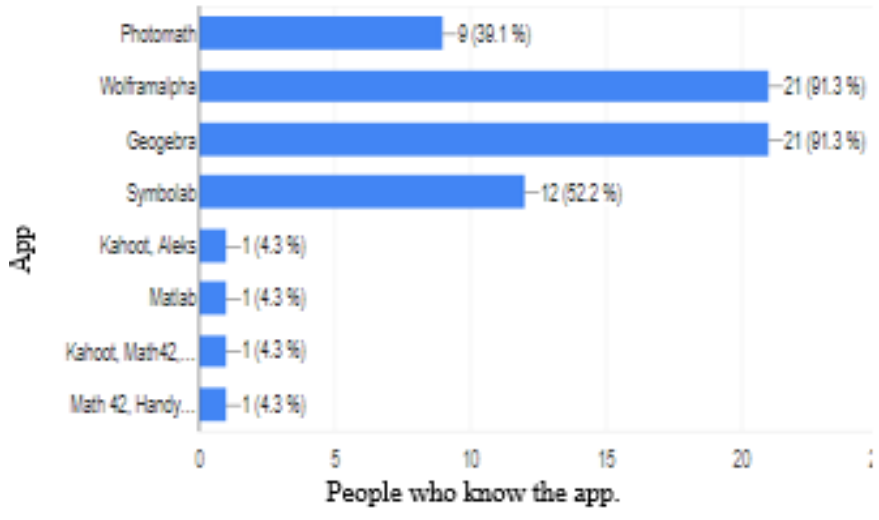

Fig. 9 Popularity of the apps among lecturers

Fig. 10 shows the frequency of use of the most popular apps among lecturers. WolframAlpha is the most used app. These data indicate that WolframAlpha has already been used as a support for lecturers in their academic activities. Moreover, lecturers know all the benefits that this app can bring as a teaching tool.

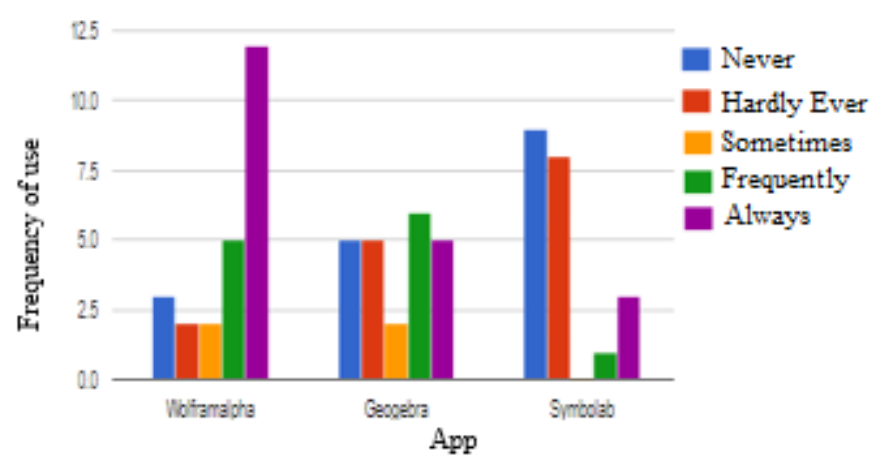

Fig. 10 Frequency of use of the apps

Finally, all lecturers have the necessary means to apply the aforementioned tools in their classes. In addition, the $100 \%$ of lecturers accept educational apps and they have the willingness to incorporate them as part of the educational process.

\section{Students' Final Survey}

The analysis of the previous surveys revealed that WolframAlpha is the optimum app that students can use as a tool for the learning process. A final survey was performed to the same group of students in order to assess the utility of this app.

As it can be observed in Fig. 11, the $85.3 \%$ of the students consider that the app is easy to use, and more than half students $(63.8 \%)$ confirm that WolframAlpha provides a great potential in the solution of pre-calculus problems.
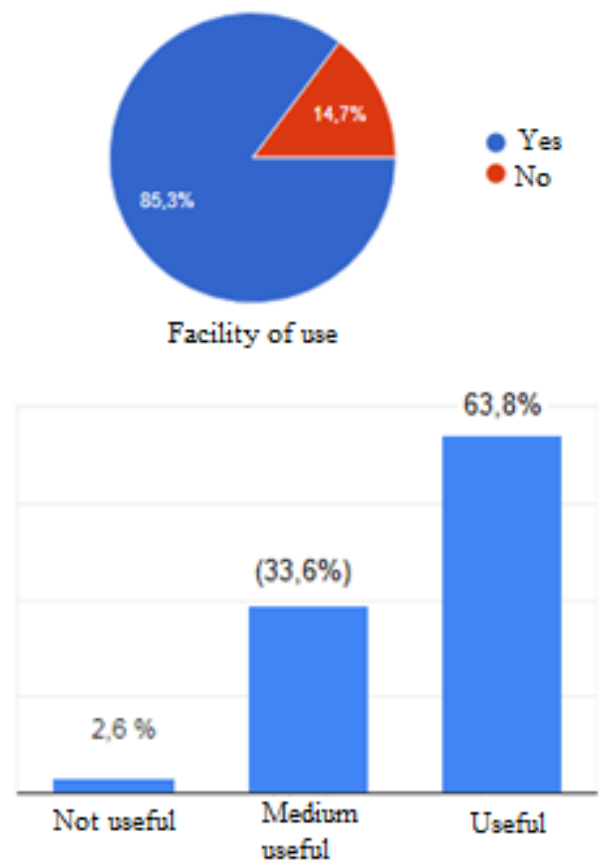

Fig. 11 WolframAlpha utility evaluation

Finally, according to the results of the last question in the poll, $81 \%$ of the students suggest that their academic performance would have increased if this app had been a tool for both lecturers and students since the begging of the current academic period.

\section{CONCLUSIONS}

It is clear that the use of ICT's in the teaching-learning process is a powerful tool for solving pre-calculus problems. Lecturers, as well as students, are willing to use these educational apps because they both agree that these apps have a great potential to improve the educational process.

According to the polls, and the comparative analysis performed in this research, WolframAlpha appears to be the ideal tool for academic purposes because of its facility of use and utility. Even though the survey was performed to only a sample of the module, it is strongly recommended to involve the use of WolframAlpha in the Academic Syllabus of the complete module. By applying this, an enhancement of the academic performance of students is expected for future academic periods.

Although both students and lecturers have the technological tools that this globalized world demands, these tools have been partially used in the academic field. In other words, these apps have been seldom used in the process of solving mathematics problems. However, the survey showed that lecturers have the willing to use these apps as a permanent tool in the educational process.

The generational change of the lecturers in the module Fundamentals of Mathematics is a main factor in the teaching process. This research reflects that most of the lecturers are between 25 and 35 years old, so the insertion of these

$1^{16}$ th LACCEI International Multi-Conference for Engineering, Education, and Technology: "Innovation in Education and Inclusion”, 19-21 July 2018, Lima, Peru. 
technological resources can be done more easily due to their greater expertise in ICT world.

\section{REFERENCES}

[1] UNESCO, "Strategic approaches on the use of ICTS in education in Latin America and the Caribbean.," 0909 2013. [Online]. Available: http://www.unesco.org. [Accessed 1502 2018].

[2] Presidency of the Republic of Ecuador, Organic Law for Higher Education, Quito, 2010.

[3] Higher Education Council, Regulation of Academic Regime, Quito, 2013.

[4] National Polytechnic School - Information and Processes Management Directorate, Strategic Plan of Information Technologies 2015 - 2020, Quito, 2015.

[5] Basic Training Department - National Polytechnic School, "Performance Report of the Students of the Leveling Course," Quito, 2017.

[6] Common Sense, "Common Sense Education," 2016. [Online]. Available: https://www.commonsense.org/education/. [Accessed February 2018].

16 $^{\text {th }}$ LACCEI International Multi-Conference for Engineering, Education, and Technology: "Innovation in Education and Inclusion”, 19-21 July 2018, Lima, Peru. 